\title{
A Study on the English Translation on Chapter Two of Tao Te Ching from the Perspective of Eco-Translatology: Lin Yutang's and James Legge's Versions
}

\author{
Peijie Yan ${ }^{1}$ (D) and Dr. Yajun Zeng ${ }^{2}$ (D) $ه$ \\ ${ }^{7}$ Yangtze University, Hubei, China \\ ${ }^{2}$ Associate professor, Yangtze University, Hubei, China \\ $\triangle$ Corresponding Author: Dr. Yajun Zeng, E-mail: zyajun@yangtzeu.edu.cn
}

\author{
ARTICLE INFORMATION \\ Received: April 08, 2021 \\ Accepted: May 10, 2021 \\ Volume: 3 \\ Issue: 5 \\ DOI: 10.32996/ijels.2021.3.5.1
}

\section{KEYWORDS}

Chu culture; ecological translation theory; Chapter two of Tao Te

Ching

\section{ABSTRACT}

Chu Culture includes material civilization and spiritual civilization created by Chu people in their working life, and it is an important part of Chinese civilization. Besides Lisao and Tianwen, Tao Te Ching by Lao Tzu is also deeply influenced by Chu culture. Under the guidance of eco-translation theory, this paper takes Chapter two of Tao Te Ching as an example, selects Lin Yutang's and James Legge's translations as the research objects, and analyzes them from the perspectives of language, culture and communication, respectively. The purpose is to explore whether the eco-translation theory can apply to the previous English translations of Tao Te Ching, and to further understand the implicit relationship between Chu culture and Tao Te Ching.

\section{Introduction 1}

Chu is not only a national concept but also a regional concept. "Chu culture is named after Chu state and Chu people. It is a regional culture of Zhou Dynasty" (Zhang, 1987). The state of Chu was founded in Hubei Province in the early Zhou Dynasty, and then developed into a southern power, including the middle and lower reaches of the Yangtze River and the Huaishui River (Gong \& Liu, 2020, P62). The emergence and development of Tao Te Ching are influenced by Chu culture, and Tao Te Ching also has a certain guiding significance for the development of Chu culture, so they two complement each other. This paper studies the English translation of Chapter two of Tao Te Ching to explore the implicit relationship between eco-translatology and previous translations to understand the applicable scope of eco-translatology.

\section{An overview of eco-translatology}

Eco-translatology has developed for seven years. First of all, in 2001, the concept of translation adaptation/selection formed when Professor Hu Gengshen read out his paper The First Exploration Of An Approach To Translation As Adaptation And Selection at The Third Asian Translators Forum. Then, in 2004, Professor Hu Gengshen's monograph of translation studies, An Approach To Translation As Adaptation And Selection was officially published in Hubei Education Press. From the perspectives of "adaptation" and "selection", Professor Hu Gengshen made new explanations on nature, process, criteria, principles and methods of translation in the book. Later, on the basis of "translation adaptation/selection theory", the research paradigm of ecotranslatology began to emerge. In 2006, Professor Hu Gengshen presented his paper Interpretation Of Eco-translatology at the International Conference On Translating Global Culture: Towards Interdisciplinary Theoretical Construction which was held in Beijing. Until then, the concept of eco-translatology has been initially shaped. In November 2007, Professor Hu Gengshen delivered a theme report entitled Ecological Turn In The Perspective Of Translatology From The Perspective Of Relevance Sequence at the Second Cross Strait Symposium On Translation And Intercultural Communication in Macao, which further introduced the concept of "ecology" into translation studies. The year of 2008 can be said to be the mature year of eco-translatology theory. Professor Hu Gengshen not only published his paper Interpretation Of Eco-translatology in Chinese Translators Journal but also won the support of the National Social Science Foundation for the title "eco-translatology: a study of eco-translatology from an

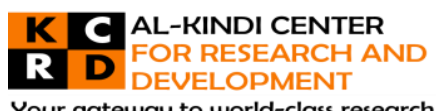

Your gateway to world-class research

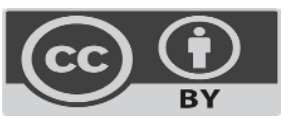

Published by Al-Kindi Center for Research and Development. Copyright (c) the author(s). This open access article is distributed under a Creative Commons Attribution (CC-BY) 4.0 license 
ecological perspective". Since then, the theory of eco-translatology has been widely used in translation studies, which has a great influence on later translation studies.

Eco-translatology holds that the eco-environment of translation is the living environment of the translator and the target text, which involves the text, geographical environment, customs and cultural context. The translation is a process of translator choices to adapt to the ecological environment of translation, and "adaptation" and "selection" are the translators' instinct in the process of translation. Its translation principle is "multi-dimensional adaptation and adaptive selection". The translators' methods can be simply summarized as three-dimensional transformation: linguistic dimension transformation, cultural dimension transformation and communicative dimension transformation. Language dimension transformation refers to "the translators' adaptive choice of language form in the process of translation"; cultural dimension transformation requires "translators pay attention to the transmission and interpretation of bilingual cultural connotation in the process of translation"; communicative dimension transformation requires "translators pay attention to the adaptive choice of bilingual communicative intention in the process of translation" (Kang et al., 2020, P26). In other words, translators should not only be faithful to the authors' intention but also play their own initiative to choose the most appropriate and ecological translation.

\section{Analysis of the Chapter Two of Tao Te Ching}

天下皆知美之为美, 斯恶已 , 皆知善之为善 , 斯不善已。

故有无相生，难易相成，长短相形，高下相倾，音声相和，前后相随。

是以圣人处无为之事，行不言之教，万物作焉而不辞，生而不有，为而不恃，功成而弗居。

夫惟弗居, 是以不去。

The meaning of these four sentences is that if everyone knows beautiful things, they also know ugly things; if they know virtuous things, they also know evil things.

Therefore, existence and nothingness, difficulties and easiness, length and shortness, win and lose, exist in opposition to each other. Because of their unification, musical notes and tones become harmonious and front and back have their own order.

As a result, sages follow the laws of nature when they teach and enlighten others by influence rather than by rules. They let everything run its own course without interference and let them develop without possession. Sages are not complacent, even if they have some achievements. What's more, they do not claim credit for themselves even if they have remarkable contributions.

It is their modesty that keeps their merits alive.

The ultimate pursuit of our human society is that everyone can live a fair, just, peaceful and stable social life like the paradise described in the Peach Blossom Spring. In Lao Zi's words, it is to make the world quiet, that is, the Communist society we are pursuing. However, since ancient times, politicians have adopted the strategies of accumulating wealth, seizing power, using all forces to wage war at will, and righteousness and ethical code to govern the country and the people. They believe that by doing these, human beings can achieve the ultimate goal of fairness, justice, peace and stability, but Lao zi pointed out that it would be impossible because if someone has money and power, someone will have no money and no power. So what about fairness and justice?

The first two sentences of this chapter describe eight pairs of opposite and unified things, for example, beauty and ugliness, virtuous and evil, existence and nothingness, difficulty and easiness, length and shortness, win and lost, musical notes and tones and front and back. They all exist because of the others' existence, because we know what beauty is, we also know what ugliness is and so on. Talking into the real world, there would have been leaders where there were groups since ancient times; someone took power as the king, someone took talent as the king, and so on. But when there was a king, there would be a rule, there would be strength and weakness, and the strong would swallow the weak, then there would be no fairness. There were many wars in the spring and Autumn period. The rulers claimed that to create a better life for the people and save the common people, but it was actually to satisfy their ambition, expand their territory and dominate the world, and ultimately the common people suffered. Therefore, Lao Tzu hoped that "sages follow laws of nature when they teach and enlighten others by influence rather than by rules", that is, he hoped that there would be no power, no politics, but society would be united, in which people lived and worked in peace and contentment in the world. Sages conformed to the laws of nature and make rules for people to follow, but they did not define what was good and what was right. Because there was virtuous, there was evil, there was right, there was wrong, people had the concept of right and wrong, the law was not easy to be firmly observed. 


\section{A three-dimensional comparison of two English versions of chapter two of Tao Te Ching (1) Adaptation and selection of language dimension}

Adaptive choice transformation of language dimension refers to the translators' adaptive choice transformation of language form in the process of translation, which can take place in different stages, levels and aspects (Hu Gengshen, 2004). In fact, there is something in common between language dimension and functional equivalence theory, that is, to choose the most appropriate description in the target culture to achieve dynamic equivalence with the source language. Generally speaking, translation should be guided by the target language readers. On the basis of fully understanding the original text, the most appropriate should be selected in the target language so that readers in the target language and the source language can get the same information and feelings.

For example, "Tianxia" originally refers to the whole world in Chinese, without geographical, temporal and spatial restrictions, but here it refers to everyone in the world. In this regard, Lin Yutang's translation is the people of the earth and James Legge's translation is all in the world. Both translators give up their literal meaning and accurately express their meaning in the text.

Lin Yutang translated "tones and voice", that is, tone harmonizes sound; James Legge translated "the musical notes and tones", which means notes and tones. Because "harmony" refers to mutual harmony and a sense of music in it, James Legge's translation is more appropriate, more able to reflect the meaning of the original, and more convenient for Western readers to understand.

In addition, the words "Wuwei" and "Buyan" do not mean "inaction" and "non-speech". As we have mentioned before, these two sentences mean that sages should comply with the laws of nature to do things and carry out enlightenment. However, Lin Yutang translated it into "Therefore the Sage: Manages affairs without action; preaches the doctrine without words;" and James Legge did it into "Therefore the sage manages affairs without doing anything, and conveys his instructions without the use of speech." The two translations are more suitable for those who know about Tao Te Ching, but most Western readers don't. Therefore, after consulting with her peer, the author translated it into: "Therefore, sages follow laws of nature when they teach and enlighten others by influence rather than by rules." The author thinks that this translation is more in line with the meaning and connotation of the original sentences.

\section{(2) Adaptation and selection of cultural dimension}

Due to the cultural differences between English and Chinese, the translator should pay attention to the conversion of Chinese and English in the process of translation, and also pay attention to the transmission and interpretation of bilingual cultural connotation in order to avoid the target readers from misinterpreting the original text from their own cultural perspective (Hu Gengshen, 2004).

On this point, we need to discuss "Wuwei" and "Buyan" in "as a result, sages follow laws of nature when they teach and enlighten others by influence rather than by rules", because these two words are not only the two words with the richest cultural connotation in this chapter but also one of the central ideas to be conveyed in Tao Te Ching. After a lot of literature review, the author summarized that scholars' explanations of "Wuwei" and "Buyan" were mainly as follows: 1) "Wuwei" actually contains two connotations of "nature" and "Wuwei": "nature" is a concept, attitude and value, as well as a state and effect; "Wuwei" is a behavior, which means a method to realize "nature" (Jin Zhu, 2012, P461). (2) Taking "Shiyi" as a further inferential marker, it is the first time to put forward an important argument about "Wuwei" in Lao Tzu. Based on the above-mentioned consensus of the first level, we can see that all things have two opposite sides. In this way, we can do things either according to the common sense of the real world or according to Lao Tzu. That is to say, "Wuwei" is not a fabricated word, but should exist. Then, based on the second level of the argument of "existence and nothingness" mentioned above, as the "nothingness" of "Tao and nothingness" is original and productive, Lao Tzu abandoned the original way of thinking in the common concept of focusing on "existence" while neglecting "nothingness" and not knowing "nothingness", and realized the shift of focus, that is to say, he emphasized the contradiction between "existence and nothingness" and gave "nothingness" positive value status. Lao Tzu used the theoretical framework of "Tao and nothingness" to control the opposite of "existence-nothingness" contained in "Wei", and regarded "Wuwei" as the highest realm of action. In fact, the proposition that "sages follow laws of nature when they teach" contains the negation of the so-called "existence" of common people. "Enlighten others by influence rather than by rules" belongs to the second sentence of antithesis. From the beginning of the first chapter, Lao Tzu has repeatedly used antithetical sentences, and the main meaning usually appeared directly in the first sentence of the antithetical sentence, and the second sentence played the role of statement. Therefore, "enlighten others by influence rather than by rules" can be regarded as the concrete expression of "sages follow laws of nature when they teach"(Xu Shan, 2020, P14-15). (3)"Tao" does nothing. It does not interfere with the development and change of all things in the world but allows them to produce, develop, move and change. In Lao Tzu's view, the political system should follow laws of nature when it teaches and enlightens others by influence rather than by rules. The monarch should not force the people to do things against their nature, but let the people live in a natural state of contentment and freedom (Cui Changqing, 1997, P51). To sum up, "Wuwei" and "Buyan" have rich cultural connotations and are unique concepts in Chinese philosophy. Daoism says that "Wu" means "You" and "You" also means "Wu". Therefore, "Wuwei" is 
not "inaction" and "Buyan" is not "no speaking". The author thinks it's better to translate this sentence into "therefore, sages follow laws of nature when they teach and enlighten others by influence rather than by rules."

(3) Adaptation and adaptive selection in communication dimension

The adaptive transformation of communicative dimension refers to the translator's attention to the adaptive transformation of bilingual communicative intention in the process of translation, which requires the translator to focus on the communicative level in addition to the transformation of linguistic information and the transmission of cultural connotation and to pay attention to whether the communicative intention in the original text is reflected in the translation (Hu Gengshen, 2004).

Tao Te Ching mainly discusses "Tao" and "Te": "Tao" is not only the way of the universe and nature, but also the way of individual practice, that is, the way of cultivating Tao; "Te" is not morality or virtue as we thought of, but a special world outlook, methodology and way of dealing with people. Lao Tzu's original intention was to teach people the method of cultivating morality. Morality is the foundation and Tao is the sublimation of morality. Without the foundation of morality, it is very likely that people will fail in dealing with the world, running the family and running the country, and they will not be able to "cultivate morality". Therefore, the cultivation of "virtue" is to create a good external environment for the cultivation of Taoism, which may also be the common need of people; the practitioners need to have a quiet state of mind and a detached life, which is also the lack of "virtue". The moral part of Tao Te Ching, which is the basis of cultivation, accounts for a large part of the text.[1]

The thought conveyed by Tao Te Ching had a great influence on both at home and abroad. At that time, World War I and World War II triggered the spiritual crisis in the western world. Western scholars felt hopeless about their own civilization system, so they began to look for antidotes from other civilization systems. As a result, some scholars put their hopes on Chinese Taoist culture and looking for a good prescription. Later, they found the idea of conforming to nature and following the trend of "Wuwei" advocated by Lao Tzu in Tao Te Ching, and believed that it could save the West. So they gave up the superiority of Western civilization and began to realize the positive significance of Lao Tzu thought. They thought that Lao Tzu thought could reduce people's selfish desire, which was of great significance for alleviating the conflicts in western society. In the last, they began to study Tao Te Ching and draw a lot of nutrients from it.

As for the sentence "it is their modesty that keeps their merits alive", it means that he will not lose his achievements because he is not proud of his merits. It just reflects Lao Tzu's idea of governing the country and also conveys the central idea of this chapter. Lin Yutang's translation is "it is because he lays claim to no credit. That the credit cannot be taken away from him" and James Legge's translation was "the work is done, but how no one can see this makes the power not cease to be" can accurately and skillfully convey the meaning of Lao Tzu and achieve the purpose of communication. In addition, in the process of learning and discussing with her peers, the author also gives a translation. That is, it is their modesty that keeps their poems alive.

\section{Concluding remarks}

Tao Te Ching is not only a manifestation of Chu culture and civilization but also a bright pearl in the long history of China. It has great guiding significance for us in ethics, morality and politics. The widespread of Tao Te Ching is a manifestation of excellent Chinese civilization and a manifestation of cultural confidence. From the perspective of eco-translatology, this paper makes a detailed comparative analysis of Lin Yutang's and James Legge's translations from three aspects and found that ecotranslatology is also applicable to the translation of ancient books. In the future translation practice, translators should bear in mind the theory of "eco-translatology", which can not only convey the meaning of the original text well but also break the confinement of the original author as the center, give full play to their subjective initiative and make the best choice to adapt to the ecological environment of the target language.

\section{References}

[1] 张正明. 1987，《楚文化史》，上海人民出版社.

[2] 龚倩,刘梦涵.关于当代楚舞研究的思考[J].舞蹈,2020(05):62-65.

[3] 胡庚申,孟凡君,蒋骁华,边立红,李素文.生态翻译学的“四生“理念——胡庚申教授访谈[J].鄱阳湖学刊,2019(06):26-33+125-126.

[4] 元连连,刘思齐,姜华.浅析生态翻译学视角下陕西文化负载词的翻译策略[J].英语广场,2020(30):26-28.

[5] 胡庚申, 2004, 《翻译适应选择论》, 武汉 : 湖北教育出版社。

[6] 金竹.《道德经》第三章四个英译本赏析[J].科技信息,2012(01):461-462.

[7] 徐山. 《老子》第二章“是以圣人处无为之事”文脉梳理[J/OL].兰州学刊:1-5[2020-12-14].

[8] 崔长青. 《道德经》英译本初探[J].国际余系学院学报, 1997(03):51-56.

[1] Fromhttps://baike.baidu.com/item/\%E9\%81\%93\%E5\%BE\%B7\%E7\%BB\%8F/327138?fr=aladdin 